\title{
[18] Electrophoretic Separation of Lymphoid Cells
}

\author{
By Ernil Hansen and Kurt Hannig
}

\section{Introduction}

The dissection of a complex system into its components, their separate analysis, and the controlled reconstitution is a scientific principle that has been used quite successfully in biochemistry. Its application in immunology calls for techniques for large-scale separation of highly pure and functionally intact lymphocyte subpopulations. Since most lymphocyte functions are mediated through their cell surface, a separation based on differences in cell membrane properties, such as surface charge, seems to be especially promising.

Preparative electrophoresis of cells became possible with the development of free-flow electrophoresis by K. Hanning. ${ }^{1-3}$ The application of this method to the separation of lymphocytes is closely connected with the name of our collegue, the late $\mathrm{K}$. Zeiller. He and a number of workers in other laboratories have demonstrated the potential of free-flow electrophoresis to efficiently separate murine $\mathrm{T}$ and $\mathrm{B}$ cells, as well as lymphocyte subpopulations at different stages of activation or differentiation (reviewed in refs. 4-9). Although most investigations have dealt with lymphocytes from mice and rats, lymphoid cells from humans, ${ }^{5,10-12}$ non-

${ }^{1}$ K. Hannig, Z. Anal. Chem 181, 244 (1961).

${ }^{2}$ K. Hannig, in "Methods in Microbiology" (J. R. Norris and D. W. Ribbons, eds.), Vol. 5, Chapter 8, p. 513. Academic Press, New York, 1971.

${ }^{3}$ K. Hannig, Tech. Biochem. Biophys. Morphol. 1, 191 (1972).

${ }^{4}$ K. Zeiller, Behring Inst. Mitt. 52, 11 (1972).

${ }^{5}$ P. Häyry, L. C. Anderson, C. Gahmberg, P. Roberts, A. Ranki, and S. Nordling, Isr. $J$. Med. Sci. 11, 1299 (1975).

' G. V. Sherbet, ed., "The Biophysical Characterization of the Cell Surface," Chapter 4, p. 36. Academic Press, New York, 1978.

${ }^{7}$ T. G. Pretlow and T. P. Pretlow, Int. Rev. Cyto. 61, 85 (1979).

${ }^{8}$ K. Shortman, H. v. Boehmer, J. Lipp, and K. Hopper, Transplant Rev. 25, 163 (1975).

${ }^{9}$ K. Shortman, J. M. Fiedler, R. A. Schlegel, D. J. V. Nossal, M. Howard, J. Lipp, and H. v. Boehmer, Contemp. Top. Immunobiol, 5, 1 (1976).

${ }^{10}$ G. Stein, H. D. Flad, R. Pabst, and F. Trepel, Biomedicine 19, 388 (1973).

11 G. Stein, Biomedicine 23, 5 (1975).

12 P. H. Chollet, P. Hervé, J. Chassagne, M. Masse, R. Plagne, and A. Peters, Biomedicine 28, 119 (1978). 